\title{
Perception of Physicians, Nurses and Employees toward Nursing Image as a Profession at Assiut University Hospitals
}

\author{
Abd elbakiy , Z., A; El- Shereef , E., A ; Youssef , H., R; \& Morsy , S., M. \\ (B. Sc. Nursing) Head Nurse at, Urology department Assiut University Hospital \\ Assist. Professor of Public Health department Faculty of Medicine Assiut University \\ Assist. Professor of nursing Administration department Faculty of Nursing. Assiut University
}

\begin{abstract}
Nursing image has been long a standing problem for nurses. Changes in health care system and public opinion have direct impact on nurses and nursing profession, the public still has a narrow view about what the profession actually does. So nurses must be concerned about negative or incorrect images; therefore public need to view the nurse as an integral part of health care system, and capable of providing holistic nursing care. Aim of this study is to assess the perception of physicians, nurses and employees toward nursing image as a profession at Assiut University Hospitals. Research design was cross- section descriptive design. The study subjects included were530 participants working at Assuit University Hospitals. The data collected through self - administered questionnaire includes demographic data sheet and nursing image questionnaire; it used for assessing the perception of physicians, nurses and employees toward nursing image. It was developed by the researcher based on related literatures and previous studied done by (Kabeel 2004). The tool consisted of six majors items each one contain number of sub items (total 41 items). The result of this study revealed that there was a statistically significant difference among the study participants regarding to the items related to the nursing image, and most factors affecting nursing profession. The study concluded that the majority of the study participants agreed that the most common factors affecting the nursing profession were: bad impression of general public about nursing profession, poor relationship between nurses and supervisors, the majority of the study participants did not prefer the nursing profession as a job, and had positive view as regards most items related to the nursing image. Based on the study findings and in order to help the nurses to be more committed for the profession and to maintain positive image as possible the following points are recommended: Activating the role of nurse and participation in decision-making, improving the communication system among nurse peers, nurse supervisors and nurse managers, successful strategies of marketing are important through the media (such as television, radio and newspapers) to maintain the powerful image of nursing profession and change negative public perception about nursing image.
\end{abstract}

\section{Key Words :Nursing image. Nursing profession.}

\section{Introduction}

Nurses are a corner stone for providing patient care and they play a key role in promoting higher standard of health care. They not only offer care and comfort but also serve as a role model Also they provide care for individuals who are healthy and ill, for all ages and cultural backgrounds, and who have physical, emotional, psychological, intellectual, social and spiritual needs (Shriver, 2007).

Nursing image has been long a standing problem for nurses. Changes in health care system and public opinion have direct impact on nurses and nursing profession. Historically public view nurse as handmaiden to physician and nursing profession seen as subordinate to medicine (Adams and Duffy, 2002). The public still has a narrow view about what the profession actually does. So nurses must be concerned about negative or incorrect images; therefore public need to view the nurse as an integral part of health care system, and capable of providing holistic nursing care (Jones, 2007).
Nursing image at the organization is very important part of recognition program designation, which sets expectations for nurse involvement in organization strategic direction and initiatives, collaborative and collegial relationships with other disciplines and respect for nurse's work (Market, 2008).

Self image is the most important one in nursing profession because nursing image influences patient care in variety of settings and nursing roles involved assessment, care planning and direct care of patient before, during and after diagnostic procedures (Walsh and Holland, 1992).

Positive nurse's image means that it is compatible with the work environment which manifested by increasing job performance, job satisfaction and low intention to work leave. In contrast, negative nurse's image means incompatibility with the work environment which manifested by frustration and job dissatisfaction (Arthur, 2006)

Significance of the study

From the researcher's experience in the field of 
nursing service, it was found that many nurses try to change their career or transfer from the hospital to another place like school of nursing; some of them are ashamed to tell many people that the nursing is their job. This might be due to public view toward nursing profession, for these reasons it was felt necessary to study this phenomenon.

\section{Aim of the study}

The present study aims to: assess the perception of physicians, nurses and employees toward nursing image as a profession at Assiut University Hospitals.

\section{Subject and Method:}

\section{Study design}

A cross sectional descriptive design was utilized to carry out the present study.

\section{Setting}

The present study was conducted at Assuit University Hospitals.

Which described as follows

\begin{tabular}{|c|l|c|c|c|}
\hline No & Characteristics & \multicolumn{3}{|c|}{ Assiut University Hospitals } \\
\hline 1 & Hospital Name & $\begin{array}{c}\text { Main } \\
\text { hospital }\end{array}$ & $\begin{array}{c}\text { Pediatric } \\
\text { hospital }\end{array}$ & $\begin{array}{c}\text { Women's } \\
\text { health } \\
\text { center }\end{array}$ \\
\hline 2 & Bed capacity & 1700 & 450 & 260 \\
\hline 3 & $\begin{array}{l}\text { Resident } \\
\text { physicians } \\
\text { numbers }\end{array}$ & 405 & 40 & 46 \\
\hline 4 & $\begin{array}{l}\text { Staff nurses } \\
\text { numbers }\end{array}$ & 1400 & 284 & 176 \\
\hline 5 & $\begin{array}{l}\text { Employees } \\
\text { numbers }\end{array}$ & 2500 & 118 & 166 \\
\hline
\end{tabular}

\section{3-Subjects:}

The participants included in the study were $10 \%$ from the total number of the resident physicians $(n=50)$, staff nurses $(n=200)$, and employees $(n=280)$ working at the previous selected hospitals.

\section{Data collection tool}

Self- administered questionnaire sheet consisted of three parts.

\section{I-Socio demographic characteristics}

It was designed to collect personal data as unit of work, age, sex, qualification, and years of experience

\section{Part II:}

Nursing image questionnaire; it used for assessing the perception of physicians, nurses and employees toward nursing image as a profession. It was developed by the researcher based on related literatures and previous studs done by (Kabeel 2004). The tool consisted of six majors items each one contain number of sub items (total 41 items) categorized as follows

\begin{tabular}{|c|l|l|}
\hline Serial & \multicolumn{1}{|c|}{ Items } & $\begin{array}{l}\text { Number } \\
\text { of items }\end{array}$ \\
\hline 1 & $\begin{array}{l}\text { Perception of study } \\
\text { participants regarding } \\
\text { public view towards } \\
\text { nursing image as a } \\
\text { profession. }\end{array}$ & 10 \\
\hline 2 & $\begin{array}{l}\text { Importance of the nursing } \\
\text { profession. }\end{array}$ & 9 \\
\hline 3 & $\begin{array}{l}\text { Nurse- supervisor } \\
\text { relationship. }\end{array}$ & 5 \\
\hline 4 & Nurse- peers relationship. & 6 \\
\hline 5 & Nurse- patient relationship. & 5 \\
\hline 6 & $\begin{array}{l}\text { Continuing education in } \\
\text { nursing field }\end{array}$ & 6 \\
\hline
\end{tabular}

Responses used 5-point Likert scale that ranging from (1) "strongly disagree" (2) "disagree" "neutral" (4) "agree" and (5) "strongly agree".

\section{Part III}

It included two open ended question namely.

1- What are the factors affecting workers employed in the nursing profession?

2-Do you prefer the nursing as a job than other professions?

The response was (yes) or (no). The participants must mention the causes of his response.

The answer of these questions was recoded by the researcher.

\section{Methods:}

\section{II-Administrative design:}

An official permission was obtained from the hospital director and the director of nursing to collect the necessary data for the present study.

\section{III-Operational design:}

The operational design was included three stages: preparatory stage, pilot study and field work.

\section{1-Preparatory phase:}

Review the available literature related to study topic using books, articles, internet resources, scientific journals and national and international studies for developing study tools. Arabic translation of the study tools was done, their content validity, reliability and stability was checked, official letters were issued from pertinent authorities.

\section{2-Pilot study:}

The pilot study was conducted to test the questionnaire clarity and understandability. It included $10 \%$ of the total study sample (5 physicians, 20 nurses and 28 employees) from the selected hospitals and excluded from the total study sample. The data collection was done by the researcher using personal interview to explain the purpose of the study and explain any item needed interpretation from the participants. Data collected from the pilot study were 
also reviewed and the necessary modifications were done prior to the final application of the study tool. It has also served in estimating the time needed for filling the questionnaire.

The results of assessment of the reliability of the study tool, by measuring its internal consistency using Cronbach's alpha coefficient method. As the table shows, all the coefficients were high, exceeding 0.5

\begin{tabular}{|l|l|c|}
\hline No & \multicolumn{1}{|c|}{ Items } & \multicolumn{1}{|c|}{$\begin{array}{c}\text { Cronbach } \\
\text { alpha } \\
\text { coefficient }\end{array}$} \\
\hline 1 & $\begin{array}{l}\text { Public view towards } \\
\text { nursing profession. }\end{array}$ & .6873 \\
\hline 2 & $\begin{array}{l}\text { Importance of the } \\
\text { nursing profession }\end{array}$ & .6771 \\
\hline 3 & $\begin{array}{l}\text { Nurse- supervisor } \\
\text { relationship }\end{array}$ & .6976 \\
\hline 4 & $\begin{array}{l}\text { Nurse- peers relationship } \\
\text { relationship patient }\end{array}$ & .6835 \\
\hline 5 & $\begin{array}{l}\text { Nurse- } \\
\text { Continuing education in } \\
\text { nursing field }\end{array}$ \\
\hline 6
\end{tabular}

\section{3-Field work:}

After making the necessary modifications to ensure the clarity of the study tool the researcher sit with each subject in the study and explained the purpose of the study and asked for participation. After obtaining verbal consent, the study tool given to the participated subject to be field through selfadministered questionnaire .This took about fifteen minutes for each participant to fill the questionnaire. The whole duration for data collection took. 6 months from "May"" to "October" 2009.

\section{Iv. Statistical Design:}

Data entry was done using Epi-info 6.04 computer software packages.

Data analysis phase was carried out via Statistical Package of Social Science (SPSS) version 16. A plan for data analysis was established based upon the objectives of the study. Data analysis began by obtaining frequency distribution and descriptive statistics for most variables. Several cross tabulations were also included As regarding to the nursing image questionnaire; The scores of each group of items were summed- up and the total divided by the number of the items in this group, giving a mean score for each group of the questionnaire the scores were converted into a percent score. The perception of the participants was positive if the percent score was $60 \%$ or more and negative if the percent score less than $60 \%$.F- Test (analysis of variance) was done to compare the perception of the studied participants A significance level of $95 \%$ with a $\mathrm{P}$ value $<0.05$ was considered.

\section{Results:}

Table (1): Shows personal and occupational characteristics of study participants at Assiut University Hospitals. The data in this table revealed that the mean age of physicians was $(26.9 \pm 3.99)$, nurses was $(29.71 \pm 8.26)$ and it was $(37.32 \pm 10.37)$ for employees. Table (2): Factors Affecting Nursing Profession. The data in this table revealed a statistical significant difference between the participants for all factors except for: the difficult nature of work, number of working hours, family and social problem and lack of job security felt by who employed in the nursing profession $(\mathrm{p}<0.05)$. Table (3): Perception of Study Participants toward the Preference of the Nursing Profession. The data in this table revealed a statistical significant difference between the participants The data in this table revealed that the majority of the participants do not prefer the nursing job as a profession for the following causes: non-respectable view of some members in the society about the nursing profession, difficult work and long working hours which contradict with the family duties and carelessness of some supervisors toward nurses Table (4): Positive and Negative View of the Study Participants toward Nursing Image The data in this table revealed a statistical significant difference between the participants for the following items: as regard the public view toward nursing image above two thirds of physicians $(66.5 \%)$ and employees $(65.4 \%)$ had a positive view as compared to nurses (46\%), as regards the nurse-peer relationship there was a significant statistical different among study participants as the majority of the nurses $(92.5 \%)$ and employees $(84.1 \%)$ had a positive view while the majority of physicians (82\%) had negative view, $(\mathrm{p}=0.000)$.also there was a significant statistical difference between study participants as regards nurse-patient relationship $\left(\mathrm{p}_{=}=0.002\right)$ and with regards to the continuous education $(\mathrm{p}=0.000)$. 
Table (1): Personal and Occupational Characteristics of the Study Participants at Assiut University Hospitals 2009.

\begin{tabular}{|c|c|c|c|c|c|c|}
\hline \multirow{2}{*}{$\begin{array}{c}\text { Personal and occupational } \\
\text { characteristics }\end{array}$} & \multicolumn{2}{|c|}{$\begin{array}{c}\text { physicians } \\
(n=50)\end{array}$} & \multicolumn{2}{|c|}{$\begin{array}{c}\text { Nurses } \\
(n=200)\end{array}$} & \multicolumn{2}{|c|}{$\begin{array}{c}\text { Employees } \\
(n=280)\end{array}$} \\
\hline & No. & $\%$ & No. & $\%$ & No. & $\%$ \\
\hline \multicolumn{7}{|l|}{ Age: (years) } \\
\hline$<25$ & 13 & 26.0 & 71 & 35.5 & 46 & 16.4 \\
\hline $25-<35$ & 26 & 52.0 & 32 & 16.0 & 31 & 11.1 \\
\hline$\geq 35$ & 11 & 22.0 & 97 & 48.5 & 203 & 72.5 \\
\hline Mean \pm SD & \multicolumn{2}{|c|}{$26.90 \pm 3.99$} & \multicolumn{2}{|c|}{$29.71 \pm 8.26$} & \multicolumn{2}{|c|}{$37.32 \pm 10.37$} \\
\hline \multicolumn{7}{|l|}{ Gender: } \\
\hline Male & 29 & 58.0 & 20 & 10.0 & 126 & 45.0 \\
\hline Female & 21 & 42.0 & 180 & 90.0 & 154 & 55.0 \\
\hline \multicolumn{7}{|l|}{ Residence: } \\
\hline Rural & 5 & 10.0 & 84 & 42.0 & 54 & 19.3 \\
\hline Urban & 45 & 90.0 & 116 & 58.0 & 226 & 80.7 \\
\hline \multicolumn{7}{|l|}{ Marital status: } \\
\hline Single & 33 & 66.0 & 52 & 26.0 & 61 & 21.8 \\
\hline Married & 17 & 34.0 & 139 & 69.5 & 214 & 76.4 \\
\hline Divorced & 0 & 0.0 & 5 & 2.5 & 1 & 0.4 \\
\hline Widow & 0 & 0.0 & 4 & 2.0 & 4 & 1.4 \\
\hline \multicolumn{7}{|l|}{ Years of experience: } \\
\hline$<5$ & 39 & 78.0 & 51 & 25.5 & 64 & 22.9 \\
\hline $5-<10$ & 9 & 18.0 & 36 & 18.0 & 48 & 17.1 \\
\hline $10-<15$ & 1 & 2.0 & 44 & 22.0 & 42 & 15.0 \\
\hline$\geq 15$ & 1 & 2.0 & 69 & 34.5 & 126 & 45.0 \\
\hline Mean \pm SD & \multicolumn{2}{|c|}{$3.673 \pm 73.73$} & \multicolumn{2}{|c|}{$11.25 \pm 7.37$} & \multicolumn{2}{|c|}{$13.15 \pm 8.99$} \\
\hline \multicolumn{7}{|l|}{ Level of education: } \\
\hline Secondary education & 0 & 0.0 & 180 & 90 & 101 & 36.1 \\
\hline High institute & 0 & 0.0 & 15 & 7.5 & 48 & 17.1 \\
\hline University education & 35 & 70 & 5 & 2.5 & 113 & 40.3 \\
\hline Postgraduate & 15 & 30 & 0 & 0.0 & 18 & 6.5 \\
\hline
\end{tabular}

Table (2): Factors Affecting Nursing Profession at Assiut University Hospitals 2009.

\begin{tabular}{|c|c|c|c|c|c|c|c|}
\hline \multirow[t]{2}{*}{ Factors } & \multicolumn{2}{|c|}{$\begin{array}{l}\text { Physicians } \\
(n=50)\end{array}$} & \multicolumn{2}{|c|}{$\begin{array}{c}\text { Nurses } \\
(n=200)\end{array}$} & \multicolumn{2}{|c|}{$\begin{array}{l}\text { Employees } \\
(n=280)\end{array}$} & \multirow[t]{2}{*}{ P-value } \\
\hline & No. & $\%$ & No. & $\%$ & No. & $\%$ & \\
\hline $\begin{array}{l}\text { 1-Nursing profession is unaccepted by } \\
\text { some members of community. }\end{array}$ & 40 & 80.0 & 176 & 88.0 & 223 & 79.6 & $0.010^{*}$ \\
\hline $\begin{array}{l}\text { 2-The difficult nature of work, number of } \\
\text { working hours and family problem. }\end{array}$ & 39 & 78.0 & 164 & 82.0 & 231 & 82.5 & 0.748 \\
\hline $\begin{array}{l}\text { 3-Nurses are usually suffering from } \\
\text { financial and physical problem }\end{array}$ & 31 & 62.0 & 144 & 72.0 & 148 & 52.9 & $0.000 *$ \\
\hline 4-The shortage of nursing staff. & 28 & 56.0 & 134 & 67.0 & 100 & 35.7 & $0.000 *$ \\
\hline $\begin{array}{l}\text { 5-Lack of opportunity in promotions and } \\
\text { raise the scientific knowledge. }\end{array}$ & 24 & 48.0 & 137 & 68.5 & 123 & 43.9 & $0.000 *$ \\
\hline $\begin{array}{l}\text { 6-Poor relationship between nurse and } \\
\text { supervisors }\end{array}$ & 21 & 42.0 & 138 & 69.0 & 154 & 55.0 & $0.000 *$ \\
\hline $\begin{array}{l}\text { 7-Lack of job security felt by workers in } \\
\text { the nursing profession. }\end{array}$ & 13 & 26.0 & 72 & 36.0 & 78 & 27.9 & 0.121 \\
\hline $\begin{array}{l}\text { 8-The impression of general public about } \\
\text { nursing profession is bad. }\end{array}$ & 28 & 56.0 & 58 & 29.0 & 81 & 28.9 & $0.000 *$ \\
\hline
\end{tabular}




\begin{tabular}{|c|c|c|c|c|c|c|c|}
\hline \multirow[t]{2}{*}{ Factors } & \multicolumn{2}{|c|}{$\begin{array}{c}\text { Physicians } \\
(n=50)\end{array}$} & \multicolumn{2}{|c|}{$\begin{array}{c}\text { Nurses } \\
(\mathrm{n}=\mathbf{2 0 0})\end{array}$} & \multicolumn{2}{|c|}{$\begin{array}{l}\text { Employees } \\
(\mathbf{n}=\mathbf{2 8 0})\end{array}$} & \multirow[t]{2}{*}{ P-value } \\
\hline & No. & $\%$ & No. & $\%$ & No. & $\%$ & \\
\hline $\begin{array}{l}\text { 9- Media and its role in publishing for } \\
\text { nursing image badly. }\end{array}$ & 26 & 52.0 & 57 & 28.5 & 85 & 30.4 & $0.005^{*}$ \\
\hline
\end{tabular}

Table (3): Perception of Study Participants toward the Preference of the Nursing Profession at Assiut University Hospitals 2009.

\begin{tabular}{|c|c|c|c|c|c|c|}
\hline \multirow[t]{2}{*}{ Items } & \multicolumn{2}{|c|}{$\begin{array}{l}\text { Physicians } \\
(n=50)\end{array}$} & \multicolumn{2}{|c|}{$\begin{array}{c}\text { Nurses } \\
(\mathbf{n}=\mathbf{2 0 0})\end{array}$} & \multicolumn{2}{|c|}{$\begin{array}{c}\text { Employees } \\
(n=280)\end{array}$} \\
\hline & No. & $\%$ & No. & $\%$ & No. & $\%$ \\
\hline \multicolumn{7}{|l|}{ Preference of nursing job as profession. } \\
\hline Yes (prefer nursing job) & 10 & 20.0 & 36 & 18.0 & 49 & 17.5 \\
\hline No (don't prefer nursing job) & 40 & 80.0 & 164 & 82.0 & 231 & 82.5 \\
\hline $\begin{array}{l}\text { Why the study participants not prefer nursing } \\
\text { job as profession? }\end{array}$ & \multicolumn{2}{|c|}{$(n=40)$} & \multicolumn{2}{|c|}{$(n=164)$} & \multicolumn{2}{|c|}{$(n=231)$} \\
\hline $\begin{array}{l}\text { 1-Non respectable view of some member in the } \\
\text { society toward the nursing profession. }\end{array}$ & 7 & 17.5 & 36 & 21.9 & 125 & 54.1 \\
\hline $\begin{array}{l}\text { 2-It is a difficult work and long working hours } \\
\text { which contradict with the family duties. }\end{array}$ & 8 & 20.0 & 49 & 29.9 & 111 & 48.1 \\
\hline 3-Lack of income as compared to the exerted effort. & 2 & 5.0 & 12 & 7.3 & 13 & 5.6 \\
\hline 4-careless of some supervisors toward nurses. & 1 & 2.5 & 36 & 21.9 & 29 & 12.6 \\
\hline
\end{tabular}

Table (4): Positive and Negative View of the Study Participants toward Nursing Image

\begin{tabular}{|c|c|c|c|c|c|c|c|}
\hline \multirow[t]{2}{*}{ Items } & \multicolumn{2}{|c|}{$\begin{array}{l}\text { Physicians } \\
\quad(n=50)\end{array}$} & \multicolumn{2}{|c|}{$\begin{array}{l}\text { Nurses } \\
(n=200)\end{array}$} & \multicolumn{2}{|c|}{$\begin{array}{l}\text { Employees } \\
(n=280)\end{array}$} & \multirow[t]{2}{*}{ P-value } \\
\hline & No. & $\%$ & No. & $\%$ & No. & $\%$ & \\
\hline \multicolumn{7}{|c|}{ 1-Public view toward nursing profession: } & \multirow{3}{*}{$0.000 *$} \\
\hline \begin{tabular}{|l|} 
Positive \\
\end{tabular} & 33 & 66.0 & 92 & 46.0 & 183 & 65.4 & \\
\hline Negative & 17 & 34.0 & 108 & 54.0 & 97 & 34.6 & \\
\hline \multicolumn{7}{|c|}{ 2-Importance of the nursing profession: } & \multirow{3}{*}{0.288} \\
\hline Positive & 49 & 98.0 & 195 & 97.5 & 266 & 95.0 & \\
\hline Negative & 1 & 2.0 & 5 & 2.5 & 14 & 5.0 & \\
\hline \multicolumn{7}{|c|}{ 3- Nurse-supervisors relation-ship: } & \multirow{3}{*}{0.287} \\
\hline Positive & 45 & 90.0 & 39 & 80.5 & 231 & 82.5 & \\
\hline Negative & 5 & 10.0 & 161 & 19.5 & 49 & 17.5 & \\
\hline \multicolumn{7}{|l|}{ 4-Nurse-peers relationship: } & \multirow{3}{*}{$0.000 *$} \\
\hline Positive & 9 & 18.0 & 185 & 92.5 & 236 & 84.3 & \\
\hline Negative & 41 & 82.0 & 15 & 7.5 & 44 & 15.7 & \\
\hline \multicolumn{7}{|c|}{ 5- Nurse's- patients relation-ship: } & \multirow{3}{*}{$0.002 *$} \\
\hline Positive & 46 & 92.0 & 196 & 98.0 & 183 & 89.6 & \\
\hline Negative & 4 & 8.0 & 4 & 2.0 & 97 & 10.4 & \\
\hline \multicolumn{7}{|c|}{$\begin{array}{l}\text { 6-The continuous education in the nursing } \\
\text { filed: }\end{array}$} & \multirow{3}{*}{$0.000 *$} \\
\hline Positive & 34 & 68.0 & 188 & 94.0 & 233 & 83.2 & \\
\hline Negative & 16 & 32.0 & 12 & 6.0 & 47 & 16.8 & \\
\hline
\end{tabular}




\section{Discussion:}

Nursing image has been long a standing problem for nurses. Changes in health care system and public opinion have a direct impact on nurses and nursing profession. Historically the public views a nurse as handmaiden to physician and the nursing profession is seen as subordinate to medicine (Reichstein and Haussler, 1994).The Poor public image of the nurse is a major organizational recruitment problem which leads to nurses' shortage and contributes to inadequate number of students entering nursing training programs (Anderson, 1998). So it is very important to promote and maintain a positive nursing image because a nurse with positive self image provides a high quality patient care and creates a comfort and safe environment (Smith, 2007).Many dollars are spent trying to rehabilitate the public image of the nurse through media campaigns for nursing future to promote nursing career as job satisfaction surveys, and various recruitment strategies (Jonson, 2005).

This study aimed to assess the perception of physicians, nurses and employees toward nursing image as a profession at Assiut University Hospitals. The findings of the present study revealed that the majority of the nurses were females. This indicates that the nursing profession still depends on women rather than men and these results were in agreement with the study findings of (Godzella and Ginther, 1995) who stated that nursing is still primarily a female profession and the women who enter nursing are attracted to the care giving and nurturing role. (Staunton, 1997) mentioned that nursing as an occupation was fundamentally "women's work" leading to a perception of nurses as ideal women and doctors as ideal men. Regarding the years of experience; the majority of physicians had less than five years of experience as the physicians were spending residency period.

The finding of the present study revealed that there was a statistical significant difference among the study participants regarding to the most common factors that affecting the employees who were working in nursing profession as shown in (Table2). Nurses had a highest mean score as compared to physicians and employees for the following factors: "nursing profession unaccepted by some of the community members". May be attributed to the bad image toward nursing profession as perceived by the public. This finding goes with the survey conducted by Buresh and Gorden, (2000) who stated that there is a major indication of unacceptance of nursing profession as compared to other professions due to lack of public understanding about the nurses and nursing roles, changing roles and the fuzzy image of nursing held by the public which lead to nurses invisibility in the media. Also, Shelley and Huffstutler, (2006) found that the negative public view toward nursing profession play a high important role in the present and the future of nursing which leads to change nursing career, leaving work and job dissatisfaction.

Difficult nature of work and long working hours were the second factors affecting nurses which lead to family and social problems. Walsh and Holland, (1992) found that if the nurses are incompatible with work environment; this will lead to frustration and job dissatisfaction. Moreover lack of flexibility of scheduling system, lack of harmony between the hours of work and family patterns lead to negligence of some family duties especially the majority of employees who are working in nursing profession were women, married and live far away from their parents and the behavior of most Egyptian men are not cooperative with their wives as regard family requirement.

Nurses were suffering from financial and physical problems due to the long distance of their residence from the hospital was the third factor affecting nurses. This is because most of them are living in small villages and the transportation unavailable most of the day. The present findings go with that of Bowen, et al, (1987) which found that $10 \%$ of nurses recorded the distance as a main factor of their decision to leave the profession, and some nurses said that the hospital's location is unsafe area which may contribute to their quitting.

The little opportunity for promotions and raising the scientific knowledge was the fourth factor affecting nurses. Majority of nurses suffered from lack of support and encouragement from other health care leaders such as nurse supervisors, nurse directors and attitude of senior nurses' staff. Also poor communication and lack of understanding between senior and junior nurses, lack of knowledge and limited leadership skill. More over there no is system for promotion in nursing profession and absent of career ladder are important factors. This finding is in accordance with that of Gillies, (1999) who found that many nurses are dissatisfied with poor quality of supervision and leadership styles and don't have experience in health care agencies.

The finding of the present study declared that some of the physicians, nurses, and employees $(20.0 \%$, $18.0 \% \& 17.5 \%$ ) respectively preferred nursing as a job (Table3). Most of them considered that nursing job generates good income; they found that nursing is interesting work and making a difference in people's lives. This finding is running in the same line with Peplau and Gamble (2009) who reported that the nursing career is a good choice for individuals who 
find pleasure in actively participating for helping others, desire to remain untiring to the extent possible and prefer a wide variety of employment opportunities?.

Also Shelley;(2000) said that nursing profession good for anyone as it offers many opportunities to learn in particular areas outside. It is an exciting professional reward. Also the nursing profession characterized by mobile or dynamic profession with many challenging and accepting individuals for financial and security reasons both nationally and internationally to make a difference to people live Furthermore the majority of employees, nurses and physicians $(80.0 \%, 82.0 \% \& 82.5 \%)$ respectively do not prefer nursing profession as a job for the following causes: difficult nature of work and number of working hours, low respect from the society and lack of recognition. This finding supported by Styles and Colleagues;(2003) who stated that the nursing is not viewed as a highly desirable career. Also nursing as a profession viewing limitations of independent work or low job autonomy as work of the nurse remains structured and generally controlled by others. This finding is in agreement with the study finding of (Kramer and Schmalenberg;2003). Who found that the nursing still works continues behind the medical profession in perception of occupational prestige and status.

The findings of the present study revealed that not all nurses but more than half of them had negative view toward nursing profession as perceived by the public. (Table,4). This might be due to that the nurses can recognize the negative comments, bad expression and actions derived from the public and patient relatives. Also nurses are suffering from the difficult working hour's exhaustion, work over load, powerlessness, low autonomy, self esteem and respect. The physicians and employees had a positive view toward nursing profession as revealed in this study. This may be due to that the nursing profession is a stable work and generates large income. This finding is in agreement with the study finding conducted by (Proter and collogues, 1998) about the nursing profession as perceived by registered nurses, physicians and general public that the nurses demonstrated the lowest score of positive responses in comparison with the physicians and employees The finding of the present study revealed that the participants had positive view as regards to continuous education. The nurses had high percentage $(94.0 \%)$ as shown in (Table,4). Continuous education is very important to increase knowledge, skills and abilities of nurses which leads to the improvement of nursing care and patient outcome, help nurses for self developing to cope with unfamiliar practice roles and rules, stimulate higher level of aspiration in low status workers and initiate movement from technical to professional levels of practice. This finding is in agreement with Beletz, (2009); and Smith and Legget, (2006) who found that the first major barrier of nursing improvement is the disunity of nursing education.

\section{Conclusion:}

In the light of the study findings, it is concluded that the majority of the study participants had positive view as regards all items related to the nursing image except for the nurses who had negative view toward nursing image as perceived by the public and the physicians who had negative view regarding nursepeer relationship.

The majority of the study participants agreed that the most common factors affecting the nursing profession were: bad impression of general public about nursing profession, physical and financial problems, poor relationship between nurses and supervisors, nursing shortage and media and its role in publishing for nursing image badly.

The majority of the study participants did not prefer the nursing profession as a job because of difficult work and long working hours which contradict with the family duties and lack of income as compared to the exerted effort and non-respectable view of some members of the society toward the nursing profession

\section{Recommendations:}

To maintain positive nursing image as possible the following points are recommended: Activating the role of nurse and participation in decision-making as an integral part of the health team. Encourage a dynamic team work between the nurses to maintain positive image and team building. Improving the communication system among nurse peers, nurse supervisors and nurse managers through regular meetings. Minimize the effort to actually members of the nursing through increasing the number of nurses and flexible work schedule as possible. Devoting much more emphasis to the reward system and support for the good example of nurses. Activating the role of the Sub-syndicate of Nursing to hold meetings and conferences for the society members in order to help them understand the importance of nursing as a profession. Successful strategies of marketing are important through the media (such as television, radio and newspapers) to maintain the powerful image of nursing profession and change negative public perception about nursing image. 


\section{References:}

1. Adams, J. and Duffy M. (2002): Secondary analysis of data potential for nursing research. Nurse investigator; 1(2): 1-2

2. Anderson, M. (1998): Nursing leadership and practice for the LPN $\backslash$ LVN. Philadelphia Davis Comp; $2^{\text {nd }}$ edition Chapter 5, pp 91-99..

3. Arthur, D. (2006): The professional self concept of nurses: A review of the literature from 19922006.Australian Journal of Advanced Nursing 2007; 24(3): 65-67

4. Beletz, E. (2009): Professionalization- a license is not enough. In chaska $2^{\text {nd }}$ edition the nursing profession. Turning points. St. C.V. Mosby. Chapter 1, p 16

5. Bowen, RJ., Schoen C., Donelan K., and Osborn R. (1987): Controlling nursing turnover. Nursing management; 18(6):66-68

6. Buresh, B. and Gardon S. (2000): From silence to voice. What nurses know and must communicate to the public. Canadian nurse association Ottawa. Retrieved from http:// nursing advocacy. Org $\backslash$ research, at 9- 2007

7. Gillies, A. (1999): Nursing management system approach. $3^{\text {rd }}$ edition W.B. Saunders Comp pp.292-304

8. Godzella, B. and Ginther D. (1995): Differences between men and women on stress producer and coping strategies. Psychological reports, 561-562

9. Internet. Nursing outlook; 55 (4): 182-188. Retrieved from http:// nursing advocacy. Org/ research.

10. Jones, J.M. (2007): Lobbyists debut at bottom of honesty and ethics list. http://www.gallup.com/poll1103123

11. Jonson, J.E. (2005): The nursing shortage. Applied nursing research 13 (3): 162-163

12. Kabeels, R. (2004): Developing tool for assessing nurses' professional identity. Thesis submitted in fluffiest of master degree in nursing administration. Faculty of nursing Cairo University.

13. Kramer and Schmalenber (2003): The nursing shortage. Is really about image http: llwww allbusiness.comlmanagement|3604934-html

14. Market, (2008): the image of nursing (Google book 2008). (http://www. Hemarketaplce. Coml the image of nursing book)

15. Peplau, H. and Gamble L. (2009): Interpersonal relations in nursing. a conceptual frame of reference. $4^{\text {th }}$ edition G.P.putnam New York Pp 12.

16. Proter, B.J. Michael J. Mary S. and Rosemary T. (1990): Enhancing the image of nursing.
Journal of nursing administration; 19 (2): 36

17. Reichsteinss, H. and Haussler S. (1994): Multicultural students' perception of nursing as a career image. Journal of nursing scholarship; 26 (1): 61-64

18. Shelley, Y. (2000): Image of nurses in motion pictures http://www.Nursingtimes;Netl nursingpractice clinical research, acute- code.

19. Shelley, Y. Huffstutler (2006): The public's image of nursing as described to baccalaureate pre nursing students. Journal of professional nursing;. 4 (1): 7-13W.B. Saunders Company

20. Shriver, S. (2007): Clinical portions of the nursing program. The disability Shriver center@. September-October 2007, 41 (5):6 www.dredf.org/.../DisRightsLawRootsPresentChallenges 10 07.pdf

21. Smith, D. and Legget P. (2007): Tobacco smoking habits across a complete cross-section of Australian nursing student. Nursing and health science; 9 (2): 82-89

22. Styles, I. Ward A. and Bosco (2003): Taking pictures. Investigating personal knowledge through illuminative artwork. Nursing times research; 5 (4): 232- 262

23. Walsh, B. and Holland L. (1992): A theory personality types and work environments. In person environment psychology model and perspectives. Lawrence Erlbaum associates publishers, Hillsdale, NJ, pp. 35- 69 